УДК 340.12

DOI https://doi.org/10.51989/NUL.2021.6.30

\title{
ЗАСТОСУВАННЯ КАТЕГОРІЇ ЧАСУ ЯК ОБ'ЄКТИВНОЇ ФОРМИ ІСНУВАННЯ МАТЕРІЇ В ОБЧИСЛЕННІ СТРОКУ ДОСУДОВОГО РОЗСЛІДУВАННЯ В РАЗІ, ЯКЩО ПІСЛЯ ЗДІЙСНЕННЯ ПОВІДОМЛЕННЯ ПРО ЗАВЕРШЕННЯ ДОСУДОВОГО РОЗСЛІДУВАННЯ ПРОКУРОРОМ ВИНЕСЕНА ПОСТАНОВА ПРО ВІДНОВЛЕННЯ СТРОКУ ДОСУДОВОГО РОЗСЛІДУВАННЯ
}

\author{
Циганюк Юлія Володимирівна, \\ доктор юридичних наук, доцент, \\ професор кафедри кримінального права та процесу \\ Хмельницького університету управління та права \\ імені Леоніда Юзькова, \\ адвокат
}

У статті досліджено питання застосування категорії часу як об'єктивної форми існування матерії, в аспекті того, яким чином відповідно до норм кримінального процесуального права та загальних засад кримінального провадження має обчислюватись строк досудового розслідування в разі, якщо після здійснення повідомлення про завершення досудового розслідування через деякий час прокурором винесена постанова про відновлення строку досудового розслідування, а ще через деякий час ухвалене нове рішення про завершення досудового розслідування.

Визначено, що питання часу $є$ ключовим у кримінальній процесуальній діяльності та знаходить своє процесуальне вираження у визначенні поняття «процесуальні строки». А така категорія, як «процесуальні строки», істотно впливає на кримінально-процесуальні правовідносини.

Відповідно до норм кримінального процесуального права та загальних засад кримінального провадження в разі, якщо після первинного повідомлення про завершення досудового розслідування через деякий час прокурором винесена постанова про відновлення строку досудового розслідування, а ще через деякий час ухвалене нове рішення про завершення досудового розслідування, строк досудового розслідування має обчислюватись за загальними правилами. У цей строк не включається строк ознайомлення з матеріалами досудового розслідування сторонами кримінального провадження в порядку, передбаченому у статті 290 Кримінального процесуального кодексу України, що відбулось після остаточного (останнього) повідомлення прокурора про завершення досудового розслідування. Строк ознайомлення з матеріалами досудового розслідування сторонами кримінального провадження на підставі попередніх повідомлень прокурора про завершення досудового розслідування включається до строку досудового розслідування.

Ключові слова: час, строк, завершення досудового розслідування, закінчення досудового розслідування.

Tsyganyuk Yulia. Application category time as objective forms of existence of matter when calculating the term of pretrial investigation in cases where after notifying the completion of pre-trial investigation prosecutors ordered the pretrial investigation term recovery

The article examines the use of the category of time as an objective form of existence of matter, in terms of how in accordance with the rules of criminal procedure law and the general principles of criminal proceedings should be calculated pre-trial investigation in the event that after notification of completion at that time, the prosecutor issued a resolution to recover the pretrial investigation, and after some time a new decision was made to complete the pre-trial investigation.

It is determined that the issue of time is key in criminal proceedings and finds its procedural expression in the definition of "procedural deadlines". And such a category as procedural deadlines significantly affects the criminal procedural legal relationship.

In accordance with the norms of criminal procedural law and general principles of criminal proceedings, if after the initial notification of the completion of the pre-trial investigation after 
some time the prosecutor issued a decision to renew the pre-trial investigation, and after some time a new decision to complete the pre-trial investigation must be calculated according to general rules. This period does not include the period of acquaintance with the materials of the pre-trial investigation by the parties to the criminal proceedings in the manner prescribed by Article 290 of the CPC of Ukraine, which took place after the final (last) notification of the prosecutor on the completion of the pre-trial investigation. The term of acquaintance with the materials of the pre-trial investigation by the parties to the criminal proceedings on the basis of previous notifications of the prosecutor on the completion of the pre-trial investigation shall be included in the term of the pre-trial investigation.

Key words: time, term, completion of pre-trial investigation, end of pre-trial investigation.

Відповідно до ст. 2 Кримінального процесуального кодексу (далі - КПК) України завданнями кримінального провадження $\epsilon$ захист особи, суспільства та держави від кримінальних правопорушень, охорона прав, свобод та законних інтересів учасників кримінального провадження, а також забезпечення швидкого, повного та неупередженого розслідування і судового розгляду для того, щоб кожний, хто вчинив кримінальне правопорушення, був притягнутий до відповідальності відповідно до своєї вини, жоден невинуватий не був обвинувачений або засуджений, жодна особа не була піддана необґрунтованому процесуальному примусу, щоб до кожного учасника кримінального провадження була застосована належна правова процедура [1].

Отже, застосування до кожного належної правової процедури віднесено законодавцем до завдань кримінального судочинства, тобто до цінностей найвищого порядку, на охорону яких спрямовано і кримінальне процесуальне законодавство, і судочинство, і діяльність правоохоронної системи. Тому завдання забезпечення належної правової процедури реалізується в багатьох інститутах кримінального провадження.

Зокрема, невід'ємним підґрунтям забезпечення належної правової процедури $\epsilon$ неухильне дотримання в роботі всіх без винятку суб'єктів кримінальної процесуальної діяльності принципу верховенства права (ст. 8 КПК України), важливою складовою частиною якого $€$ правова визначеність. Європейський суд з прав людини в низці рішень підкреслює, що найбільш важливим захистом від свавілля влади $\epsilon$ вимога того, щоб усі дії влади відповідали закону. Національне законодавство має передбачати міри захисту від довільного втручання публічної влади у здій- снення прав, гарантованих Конвенцією (наприклад, рішення Європейського суду від 26 квітня 1979 р. у справі ««Санді Таймс» проти Сполученого Королівства» ("'The Sunday Times" v. United Kingdom") (№ 1); постанова від 25 березня 1983 р. у справі «Сілвер та інші проти Сполученого Королівства» ("Silver and Others v. United Kingdom"); постанова від 2 серпня 1984 р. у справі «Мелоун проти Сполученого Королівства» ("Malone v. United Kingdom"); постанова Великої палати у справі ««Чентро Європа 7 С.р.л.» та Ді Стефано проти Італії» ("'Centro Europa 7 S.r.I." and Di Stefano v. Italy"), скарга № 38433/09).

Згідно з усталеною практикою Європейського суду поняття «якість закону» означає, що національне законодавство повинне бути доступним і передбачуваним, тобто визначати досить чіткі положення, щоби дати людям адекватну вказівку щодо обставин і умов, за яких державні органи мають право вживати заходів, що вплинуть на права осіб (дивись, наприклад, постанову від 27 травня 2013 р. у справі «Олександр Волков проти України», заява № 21722/11) [2]. Окрім того, як зауважує Т. Кравцова, Європейський суд зазначає, що відповідальність за подолання недоліків законодавства, правових колізій, прогалин, інтерпретаційних сумнівів лежить, серед іншого, і на судових органах, які застосовують та тлумачать закони (рішення від 11 квітня 2013 р. у справі «Вєрєнцов проти України», заява № 2037/11) [3].

Відповідні положення знаходять послідовне втілення і в національному законодавстві. Зі змісту ст. 19 Конституції України, ст. ст. 1, 7, 8, 9, 36 КПК України, ст. ст. 3, 4, 22, 25 Закону України «Про прокуратуру» недвозначно випливає, що прокурор під час здійснення своїх повноважень у кримінальному провадженні має 
право вчиняти лише ті дії, які передбачені кримінальним процесуальним законодавством.

Згідно з п. 14 ст. 92 Конституції України виключно законами України визначаються судоустрій, судочинство, статус суддів; засади судової експертизи; організація і діяльність прокуратури, нотаріату, органів досудового розслідування, органів і установ виконання покарань; порядок виконання судових рішень; засади організації та діяльності адвокатури [4].

Відповідно до ч. ч. 1, 2 ст. 1 КПК України порядок кримінального провадження на території України визначається лише кримінальним процесуальним законодавством України. Кримінальне процесуальне законодавство України складається з відповідних положень Конституції України, міжнародних договорів, згода на обов'язковість яких надана Верховною Радою України, цього Кодексу й інших законів України [1]. Отже, нормативні акти підзаконного відомчого характеру не $\epsilon$ частиною кримінального процесуального законодавства України тоді, коли вони суперечать змісту закону, невиправдано і безпідставно розширяють права владних суб'єктів.

Результатами аналізу норм вітчизняного кримінального процесуального законодавства та з огляду на сталу практику міжнародних стандартів переконливо доводиться, що реалізація прокурором у кримінальному провадженні повноваження, не передбаченого кримінальним процесуальним законодавством, грубо суперечить загальним засадам кримінального провадження, порушує принцип верховенства права та від самого початку ставить під сумнів справедливість судового розгляду.

Очевидно, що чинне кримінальне процесуальне законодавство безпосередньо не передбачає інституту «відновлення прокурором строку досудового розслідування» після ухвалення рішення про його завершення. Тобто винесення прокурором постанови про відновлення строку досудового розслідування само собою містить загрозу порушення Конвенції про захист прав та свобод людини та ст. ст. 7, 8, 9, 36 КПК України.

Водночас вітчизняне кримінальне процесуальне законодавство має низку про- галин. Недарма судді та науковці наголошують, що процесуальні можливості учасників кримінального провадження в період від завершення до закінчення досудового розслідування потребують конкретизації та більш чіткої нормативної реґламентації [5]. Положення КПК не регулюють питання кримінального провадження на етапі між завершенням досудового розслідування та його закінченням.

Норми законодавства, як і судова практика та доктрина кримінального процесу, послідовно розмежовують моменти завершення досудового розслідування та його закінчення. Зокрема, у постанові від 7 лютого 2021 р. у справі №344/6630/17 Верховний Суд зазначив, що досудове розслідування, яке має наслідком звернення до суду з обвинувальним актом або із клопотанням про вжиття примусових заходів, має три ключові віхи: початок - визначається внесенням відомостей до Єдиного реєстру досудових розслідувань (далі - ЄРДР); завершення - пов'язується 3 фактом відкриття матеріалів досудового розслідування підозрюваному, його захиснику, законному представнику, захиснику особи й іншим особам відповідно до положень ст. 290 КПК; закінчення - фіксується направленням до суду обвинувального акта, клопотання про застосування примусових заходів медичного або виховного характеру [6].

Завершення досудового розслідування та надання стороні захисту можливості ознайомлення з матеріалами кримінального провадження $\epsilon$ підставою для виключення строку ознайомлення зі строку досудового розслідування. 3 огляду на те, що законодавчі обмеження на проведення слідчих (розшукових) дій «прив'язані» саме до закінчення, а не до завершення досудового розслідування, саме вплив цього рішення на можливе призупинення строку досудового розслідування стає його основним, сутнісним значенням.

Виключаючи строк ознайомлення з матеріалами справи зі строку досудового розслідування, законодавець керувався певними підставами. Зауважимо, що кримінально-процесуальне регулювання нині детально нормує забезпечення розумних строків судового розгляду. Засада розумності строків кримінального провадження 
випливає із завдання швидкого розслідування і судового розгляду, закріпленого у ст. 2 КПК, і відповідає вимогам ст. 6 Європейської конвенції про захист прав людини і основоположних свобод 1950 р., яка гарантує, що кожен має право на справедливий і публічний розгляд його справи впродовж розумного строку незалежним і безстороннім судом [7, с. 64]. Це право, передбачене ст. 6 Конвенції про захист прав людини та основоположних свобод, отримує суворий захист. За порушення строків встановлюються санкції, передусім для тих учасників кримінального провадження, які діють від імені держави. Закономірним $є$ запровадження закриття кримінального провадження через те, що після повідомлення особі про підозру закінчився строк досудового розслідування (п. 10 ч. 1 ст. 284 КПК України). Очевидно, що закриття провадження в такому разі $\epsilon$ своєрідною санкцією за порушення обов'язку дотримання розумних строків.

Тому здійснення досудового розслідування чітко обмежується часовими рамками, визначеними ст. 219 КПК України. Здійснення ж досудового розслідування за межами цього строку $\epsilon$ неприпустимим. Різноманітні спроби обійти встановлені законом строки шляхом неофіційного розслідування, що передує внесенню відомостей до ЄРДР, штучного виділення й об'єднання кримінальних проваджень, винесення формальних і необґрунтованих постанов про зупинення досудового розслідування тощо, здебільшого усунуті шляхом внесення змін до законодавства.

Отже, призупинення перебігу стоку досудового розслідування на період ознайомлення сторін із матеріалами кримінального провадження зумовлене не тільки залежністю тривалості строку ознайомлення від поведінки сторони захисту, але і неможливістю сторони обвинувачення здійснювати в цей період досудове розслідування. Саме такою $€$ логіка законодавця. Модель чинного КПК України розбудована таким чином, що після ухвалення рішення про завершення досудового розслідування має слідувати етап ознайомлення сторін із матеріалами кримінального провадження, за яким - закінчення досудового розслідування в одній із передбачених законом форм. Деформація цієї моделі на практиці спричинені, вірогідно, неправильним правозастосуванням, відсутністю справжньої змагальності під час досудового розслідування, помилками правоохоронних органів тощо. Наслідком цього є складні ситуації, які мають бути оцінені судами та втілюються в ухвалення рішень, подібних до постанови Верховного Суду від 7 лютого 2021 р. у справі № 344/6630/17.

У вказаному рішенні Верховним Судом фактично зроблено висновок про можливість для сторони обвинувачення визнати своє попереднє рішення про завершення досудового розслідування передчасним, позбавити його правового значення та повернутися на попередній етап [6]. Також важливі й інші аспекти позиції, відтвореної в цитованій постанові Верховного Суду. У разі вчинення стороною обвинувачення після ухвалення рішення про завершення досудового розслідування слідчих і процесуальних дій, після їх проведення алгоритм дій сторони обвинувачення в повному обсязі визначається ст. 290 КПК України. Тобто прокурор має цілком повторити встановлену процедуру - ухвалити нове рішення про завершення досудового розслідування, відкрити стороні захисту всі матеріали кримінального провадження тощо [6].

Також у цитованому рішенні Верховний Суд наголосив на тому, що слідчі та процесуальні дії мають бути проведені суто в межах строку досудового розслідування [6]. Цілком логічно, що в разі визнання прокурором первинного рішення про завершення досудового розслідування помилковим, таке рішення не може створювати процесуальних наслідків. Оскільки воно вже не сприймається як таке, що завершує досудове розслідування, воно не може сприйматись і як таке, що зупиняє строк досудового розслідування. Отже, первинне рішення прокурора про завершення досудового розслідування втрачає своє значення. I загальні засади кримінального процесуального права, серед яких верховенство права, законність, рівність перед законом і судом, розумність строків, вимагають, щоб втрата ним свого значення в частині завершення досудового розслідування симетрично доповнювалась 
втратою значення підстави для зупинення строку досудового розслідування.

Отже, кримінальному процесуальному законодавству не суперечить, що прокурор має право ухвалити рішення про завершення досудового розслідування стільки разів, скільки вважатиме за потрібне. Однак правове значення рішення про завершення досудового розслідування буде мати лише останнє таке повідомлення. Тому зі строку досудового розслідування виключенню підлягає лише строк остаточного (останнього за часом) ознайомлення сторони захисту з матеріалами досудового розслідування. «Невдале», первинне повідомлення про завершення досудового розслідування не повинно наділятися такими правовими наслідками, які передбачені ст. ст. 219, 290 КПК України, тобто не може бути підставою для виключення строку ознайомлення сторони захисту з матеріалами кримінального провадження зі строку досудового розслідування.

Забезпечення балансу прав сторін кримінального провадження, що $\epsilon$ невід'ємною складовою частиною справедливості провадження, передбачає, що жодна з них не отримуватиме преференцій унаслідок маніпуляцій і порушення законодавства. Тому можливість сторони обвинувачення проводити слідчі та процесуальні дії і після того, як нею було ухвалене рішення про завершення досудового розслідування, має врівноважуватись тим, що час, протягом якого досудове розслідування фактично здійснювалось усупереч попередньому рішенню про його завершення, включається до строку досудового розслідування. Саме такий підхід відповідає загальним засадам кримінального судочинства й узгоджується з актуальною судовою практикою, зокрема і з висловленим у постанові Верховного Суду від 7 лютого 2021 р. у справі № 344/6630/17 твердженням про те, що законодавчі обмеження на проведення слідчих (розшукових) дій «прив'язані» саме до закінчення, а не до завершення досудового розслідування.

Для визначення строку досудового розслідування в такому разі винесення прокурором постанов «про відновлення строку досудового розслідування» та подібних, не передбачених законом рішень, будьякого значення не має і взагалі не повинно братися до уваги.

Отже, у підсумку необхідно зазначити такі висновки. Питання часу $\epsilon$ ключовим у кримінальній процесуальній діяльності та знаходить своє процесуальне вираження у визначенні поняття «процесуальні строки». А така категорія, як «процесуальні строки», істотно впливає на кримінально-процесуальні правовідносини.

Відповідно до норм кримінального процесуального права та загальних засад кримінального провадження в разі, якщо після первинного повідомлення про завершення досудового розслідування через деякий час прокурором винесена постанова про відновлення строку досудового розслідування, а ще через деякий час ухвалене нове рішення про завершення досудового розслідування, строк досудового розслідування має обчислюватись за загальними правилами. У цей строк не включається строк ознайомлення з матеріалами досудового розслідування сторонами кримінального провадження в порядку, передбаченому ст. 290 КПК України, що відбулось після остаточного (останнього) повідомлення прокурора про завершення досудового розслідування. Строк ознайомлення з матеріалами досудового розслідування сторонами кримінального провадження на підставі попередніх повідомлень прокурора про завершення досудового розслідування включається до строку досудового розслідування.

\section{ЛITEPATУРА:}

1. Кримінальний процесуальний кодекс України від 13.04.2012 р. № 4651-VI. URL: https://zakon.rada.gov.ua/laws/show/4651-17\#Text.

2. Рішення Солонянського районного суду Дніпропетровської області від 20 жовтня 2021 р. Справа № 192/25/21. URL: https://youcontrol.com.ua/ru/catalog/court-document/100447425/.

3. Кравцова Т. Правова визначеність: основні принципи та практика Європейського суду. ЮрЛіга. 11 червня 2019 р. URL: https://jurliga.ligazakon.net/experts/65/885_pravovaviznachenst-osnovnprintsipi-ta-praktika-vropeyskogo-sudu. 
4. Конституція України : Закон від 28.06.1996 р. № 254к/96-BP. URL: https:// zakon.rada.gov.ua/laws/show/254\%D0\%BA/96-\%D0\%B2\%D1\%80\#Text.

5. Михайленко В. Завершення і закінчення досудового розслідування: гра слів чи різні етапи досудового розслідування. Юридична газета. 14 травня 2020 p. URL: https:// yur-gazeta.com/publications/practice/sudova-praktika/zavershennya-i-zakinchennyadosudovogo-rozsliduvannya-gra-sliv-chi-rizni-etapi-dosudovogo-rozsliduva.html.

6. Постанова Касаційного кримінального суду Верховного Суду від 7 лютого 2021 р. Справа № 344/6630/17. URL: https://reyestr.court.gov.ua/Review/95067240.

7. Яновська О. Забезпечення дотримання розумних строків на стадії підготовчого провадження. Вісник кримінального судочинства. 2016. № 1. С. 66-69. 